The Labore Journal of Economics

Special Edition (September 2007)

\title{
Financial Sector Restructuring in Pakistan
}

\section{Muhammad Arshad Khan and Sajawal Khan*}

\begin{abstract}
In this paper an attempt has been made to review the financial restructuring process and its importance for economic growth and macroeconomic stability. The main focus is on the financial restructuring efforts undertaken by the government of Pakistan since 1990. We also analyze the impact of financial restructuring by using various financial indicators. The overall results suggest that the financial industry in Pakistan is showing remarkable and unprecedented growth. Unlike 1990, the performance of the financial sector is much better today. After the successful completion of first generation reforms, the introduction of second generation reforms is required, which will help to further strengthen the financial system and transfer the benefits of the first generation reforms to society.
\end{abstract}

\section{Introduction}

In a modern economy, an efficient financial system is essential to facilitate economic transactions, specialize in production, and establish investor-friendly institutions and competitive markets. A stable and efficient financial system not only reduces uncertainty and the cost of transactions but also improves overall economic efficiency through the efficient allocation of resources. A more balanced and vibrant financial system will contribute to economic growth and the stability of the economy. In contrast, regulated financial systems lead to underdeveloped and incompetitive markets, with a financial sector dominated by government owned financial institutions that impose constraints on economic growth. It is now widely recognized that weak and inefficient financial systems are more vulnerable to contagion, less able to cope with volatile capital flows and exchange market pressures, and more likely to propagate and magnify the effects of financial crises. This

\footnotetext{
* The authors are respectively Associate Professor Government Post-graduate College Muzaffarabad (Azad Kashmir) and Lecturer Government Degree College Ghazi, Haripur (NWFP) and both are currently working as Research Associates, Pakistan Institute of Development Economics, Islamabad.
} 
recognition has highlighted the need for the global adoption of strengthened standards for banking supervision (IMF, 1996). The appropriate sequencing of financial sector restructuring and supervision policies have also become pressing issues in many LDCs, where a large part of the banking system is undercapitalized and insolvent, reflecting major macroeconomic shocks, large structural changes and weak banking supervision. The resulting distress in the financial system has, in turn, complicated monetary management and affected the effectiveness of stabilization policies (Sundararajan, 1996).

Since the early 1990s, many developing countries have started to restructure their financial sector as a part of broader Structural Adjustment Programs (SAP) which includes fiscal consolidation, reforms of the trade and exchange rate systems, price liberalization, deregulation of financial sector activities and other wide-ranging measures to enhance efficiency and supply responsiveness of the economy. These reforms were expected to bring about significant economic benefits, particularly through a more effective mobilization of domestic savings and efficient allocation of resources. Policies for restructuring the domestic financial system are aimed at strengthening the role of market forces and competition through liberalization of interest rates, adoption of indirect monetary instruments, strengthening of prudential supervision and related market information systems in order to deal effectively with interest rate and exchange rate risks and other banking risks, particularly in the context of capital account liberalization by enhancing banks' soundness and by promoting equity markets (IMF, 1995). Moreover, the liberalization of current and capital account transactions are aimed at better integrating the domestic financial system into world financial markets.

During the pre-reform period, the financial sector in Pakistan mainly accommodated the financing needs of the government, public enterprises and priority sectors. Private sector investment remained modest, and efforts to mobilize savings lacked the dynamism of a competitive financial system. Financial intermediaries were insulated from competition in the domestic market through oligopolistic practices and barriers to entry in the sector, and from outside competition through tight restrictions on current and capital accounts transactions (Khan, 1995).

In such an environment, which was typical of many pre-reform situations, distortions were widespread, interest rates were generally negative in real terms, incentives were provided to inefficient investment, credit was rationedon the basis of government determined priorities and excessive regulations hindered the activities of financial intermediation. Consequently, economic efficiency remained low and growth suffered from relatively low savings and investment rates in the private sector. 
Like many other developing countries, Pakistan undertook the process of financial restructuring through reforms in the early 1990s to establish a more market-based system of financial intermediation and government financing, conduct monetary policy more efficiently through greater reliance on indirect instruments and contribute to the rapid development of the stock markets. These reforms were primarily designed to correct the distortions implicit in the administered structure of rates of returns on various financial instruments, to abolish the directed and subsidized credit schemes, to allow the free entry of private banks in the financial sector in order to enhance competition and efficiency in the financial sector and to strengthen the State Bank of Pakistan's (SBP) supervision.

The main objective of this paper is to examine the financial restructuring efforts undertaken by the government of Pakistan to gain efficiency in the financial sector. Moreover, the study also examines the outcomes resulting from financial restructuring and suggests further improvement in this regard. The rest of the study is structured as follows: Section 2 discusses the theoretical rationale of financial restructuring. Section 3 describes the financial restructuring process carried out so far in Pakistan, while Section 4 assesses the results of restructuring in Pakistan. Some concluding remarks are given in Section 5.

\section{Theoretical Rationale of Financial Sector Restructuring}

The theoretical support for financial restructuring as a policy goal can be traced back to the fundamental theorem in welfare economics and the efficient market hypothesis. The fundamental theorem suggests that competitive markets lead to Pareto optimal equilibria, while the efficient market hypothesis argues that the financial sector uses market information efficiently. A combination of these two ensures the efficiency in the financial sector. The reform of the financial system removes market distortions that impede free market conditions (Eatwe11, 1996; Mavrotas and Kelly, 2001). Mckinnon (1973) and Shaw (1973) argued that financial deepening is an essential ingredient to the process of capital accumulation, which in turn enhances economic growth through savings and investment. They further stated that financially repressed economies remain below its market clearing values thereby generating less than the optimal amount of savings and thus detracting from the pool available for investment. The policy message is that both financial and real sector development requires a comprehensive package of financial restructuring that frees up interest rates to their market-clearing levels and eliminates administratively-determined selective credit allocation (Chowdhury, 2000). 
There is now general agreement among economists that inappropriate regulatory and supervisory policies not only retard long-term economic growth but also increase the likelihood of a financial crisis that could spread beyond the country's own borders. Table-1 provides the importance of prudential and related regulations in the efficient management of the financial system.

\section{Table-1: Types of Financial Regulation: Objectives and Key Policy Instruments}

\begin{tabular}{|c|c|c|}
\hline $\begin{array}{c}\text { Type of } \\
\text { Regulation }\end{array}$ & Objectives & Key Policy Instruments \\
\hline $\begin{array}{l}\text { Macro- } \\
\text { economic }\end{array}$ & $\begin{array}{l}\text {-To maintain control over } \\
\text { aggregate economic activity. } \\
\text {-To maintain internal and } \\
\text { external balance }\end{array}$ & $\begin{array}{l}\text { Reserve requirements, direct } \\
\text { credit and deposit ceilings, } \\
\text { interest rate controls, } \\
\text { restrictions on foreign capital }\end{array}$ \\
\hline Allocative & $\begin{array}{l}\text {-To influence the allocation } \\
\text { of financial resources in } \\
\text { favour of priority activities. }\end{array}$ & $\begin{array}{l}\text { Selective credit allocation, } \\
\text { compulsory investment } \\
\text { requirements, preferential } \\
\text { interest rates. }\end{array}$ \\
\hline Structural & $\begin{array}{l}\text {-To control the possible } \\
\text { abuse of monopoly power } \\
\text { by dominant firms. }\end{array}$ & $\begin{array}{l}\text { Entry and merger controls, } \\
\text { geographic and functional } \\
\text { restrictions. }\end{array}$ \\
\hline Prudential & $\begin{array}{l}\text {-To preserve the safety and } \\
\text { soundness of individual } \\
\text { financial institutions and } \\
\text { sustain public confidence in } \\
\text { systemic stability. }\end{array}$ & $\begin{array}{l}\text { Authorization criteria, } \\
\text { minimum capital } \\
\text { requirements, limits on the } \\
\text { concentration of risks, } \\
\text { reporting requirements. }\end{array}$ \\
\hline Organizational & $\begin{array}{l}\text {-To ensure smooth } \\
\text { functioning and integrity of } \\
\text { financial markets and } \\
\text { information exchanges }\end{array}$ & $\begin{array}{l}\text { Disclosure of market } \\
\text { information, minimum } \\
\text { technical standards, rule of } \\
\text { market making and } \\
\text { participation. }\end{array}$ \\
\hline Protective & $\begin{array}{l}\text {-To provide protection to } \\
\text { users of financial services, } \\
\text { especially consumers and } \\
\text { non-professional investors. }\end{array}$ & $\begin{array}{l}\text { Information disclosure to } \\
\text { consumers, compensation } \\
\text { funds, ombudsmen to } \\
\text { investigate and resolve } \\
\text { disputes. }\end{array}$ \\
\hline
\end{tabular}

Source: Vittas (1992, p. 63) 
It is clear from Table-1 that the debate relating to liberalization has focused on the allocative aspect of the financial sector rather than prudential, organizational and protective regulations because of information problems. Barth, et. al. (1998) suggest that the following initial steps should be taken to reduce the likelihood of a financial crisis:

- Develop and improve legal systems and information disclosure;

- Impose rate ceilings on bank deposits;

- Establish limits on the rate at which banks can expand credit or on the rate of increase in their exposure to certain sectors, such as real estate;

- $\quad$ Required greater diversification of bank portfolios; and

- Reduce the restrictions on the range of activities in which banks can engage.

They maintain that it is not possible to determine a priori which combination is most appropriate for individual countries because of the different stages of development. Despite this, it would be essential to maintain that the central purpose of prudential and organizational regulations is to deal with failures associated with moral hazard while protective regulations focus on the need to design a fair financial system that protects the interests of the users of financial services.

Sheng (1996) defined financial restructuring as "the package or macroeconomic, microeconomic, institutional and regulatory measures taken to restore problem banking system to financial solvency and health". The problem banking system may be defined in terms of non-performing loans (NPLs) and shortfall of credit requirements. Sheng states that "as a rule of thumb, banking distress is likely to become systemic when NPLs, net of provisions reached roughly $15 \%$ of the total loans". The Narasimham Committee on Banking Sector Reforms (1998) defines that "a weak bank should be one whose accumulated losses and net NPLs exceed its net worth or one whose operating profits less its income on recapitalization bonds is negative for three consecutive years". Practically, financial restructuring is a complex process but it strengthens the balance sheet structure of banks and non-bank financial intermediaries (NBFIs). It can be argued that appropriate efforts are necessary to reverse the insolvency and poor profitability of banks. Moreover, the regulatory environment and supervisory institutions must be modernized and restructured (Hoelscher, 1998). These steps are 
necessary to ensure that banking failure does not jeopardize the stability of financial institutions. The process of financial restructuring consists of four phases i.e. diagnosis, damage control, loss allocation and rebuilding profitability and creating the right incentives. If the diagnosis is done correctly, it would help the banks to know the extent and causes of loss by applying uniform accounting and auditing standards - especially loan classifications and interest accrual standards - for all banks. Damage control is basically intended to stop the flow of future losses either by liquidating, enforcing hard budget constraints, changing management, etc. Loss allocation among different parties ${ }^{1}$ is the most difficult part of financial restructuring and successful restructuring depends on the loss allocation. Finally, rebuilding profitability and creating the right incentives requires good policies, reliable and efficient management and a strong institutional framework.

There are two types of restructuring mechanism: one is market based solutions such as shareholder capital injection, sale or merger, liquidation without deposit compensation, etc. and the other involves government intervention such as liquidation with deposit insurance, formation of asset recovery trust, supply side solutions, etc ${ }^{2}$. Dziobek and Pazarbasioughu (1988) propose two types of restructuring mechanisms: financial and operational restructuring. According to them, the aim of the restructuring program is to restore the solvency and profitability of the banks. Bank solvency would emanate from shorter-term financial restructuring measures such as capital injection, long-term loans, swapping bonds for NPLs, etc. While a return to profitability requires more difficult and longer-term operational restructuring such as improved cost effectiveness, better internal governance, effective risk management, etc. Hence, bank insolvency is dealt with by financial restructuring, while poor profitability is caused by some combination of NPLs and high operating costs. These problems are dealt with through operational restructuring.

Mishkin (1996) has noted that "a non-linear disruption to financial markets in which adverse selection and moral hazard problems become much worse, so that the financial markets are unable to efficiently channel funds to economic agents who have the most productive investment opportunities". There are four factors promoting a financial crisis: increases in interest rates, increases in uncertainty, asset market effects on balance sheets, and bank panics. Hence, a strong regulatory and supervisory system is necessary to cope with a financial crisis and promote the efficient functioning of financial

\footnotetext{
${ }^{1}$ Such as, owners, borrowers, depositors, regulators and government.

${ }^{2}$ See Sheng (1996), p. 36.
} 
markets. Caprio and Klingebiel (1997) showed that a mixture of bad policies and bad banking causes bank insolvency. Furthermore, excessive expansion of credit is also one of the main causes of insolvency. Besides bad banking and excessive credit expansion, there are many causes which are cited in the literature such as asset-liability mismatches, insufficient diversification, directed lending, fraud, etc. Therefore, the challenge is to devise an appropriate regulatory framework that enables the banking system to be more resilient to insolvency. In addition, timing, sequencing, and speed of restructuring measures are very important for successful restructuring (Khatkhate, 1998 and Alawode and Ikhide, 1997).

The experiences of economies in transition illustrate that the sequencing of bank restructuring and supervision policies have had a great impact on macroeconomic performance and financial market development. In Eastern and Central Europe, bank restructuring policies-recapitalization with government funds (Hungary, Czechoslovakia, Poland), carving out bad loans (Poland, Czech Republic), conversion of enterprise debt-to-equity (Bulgaria and Croatia) - were implemented in varying degrees since 1991 (Sundararajan, 1996). The effectiveness of financial restructuring requires sustained efforts towards stabilization and proper design and the enforcement of bank restructuring and prudential supervision policies in order to avoid major disruption to growth and stability.

The sequencing of financial restructuring and prudential supervision policies may be divided into three stages (Sundararajan, 1994 and Alexander et al, 1995). These three stages (Table-2) can provide guidelines for every country, pursuing restructuring and financial liberalization policies.

Table-2: Financial Restructuring during the Various Stages of Financial Sector Reform

\section{Stage 1: Preparatory}

The preparatory stage include:

- Introduction of a minimal program of financial restructuring policies to deal with fixed rate loans, selected nonperforming loans, capital adequacy and subsidized selective credit.

- Review of legal and organizational arrangements for banking supervision.

- Strengthen the licensing and entry regulations. Put in place a framework for orderly intervention and liquidation of banks. 


\section{Stage 2: Initiating Market Development}

This stage includes the following measures:

- Phase in the reform of commercial bank accounting and bank reporting systems, help to enforce prudential norms and facilitate monetary analysis.

- Phase in the prudential regulations, particularly loan classification and provision, credit concentration limits, credit appraisal guidelines and foreign exchange exposure rules based on new accounting standards.

- Strengthen and phase in the capital adequacy norms in line with bank restructuring strategy.

- Introduction of a strategy to combine off-site, on-site, and external audit, and the balance among the components such as the availability of resources and technical assistance.

- Active pursuit of institutional development of banks.

- Formulation of a comprehensive program of bank restructuring, bank liquidations, loan recovery and loan workout arrangements. Implementation of simple financial restructuring policies for banks - supported by enterprise financial restructuring (e.g. policies to reduce debt-equity ratio of non-financial firms and recapitalize banks through portfolio restructuring) as a part of this program.

\section{Stage 3: Strengthening Financial Markets}

During this stage the following steps are needed:

- Continuation of comprehensive reforms to foster bank and enterprise restructuring systematically in line with the program designed in stage 2 .

- Promotion of well-capitalized and well-supervised dealers in government securities (and money market instruments) as part of strengthening security market regulations and supervision.

- Completion of reforms of bank accounting and prudential standards.

- Strengthen financial risk management in payment systems.

- Strengthen supervision of asset-liability management (interest rate risks, liquidity management), internal controls, and management systems of banks. 
- Achievement of appropriate balance between off-site supervision, on-site inspection and external audit through technical assistance and training.

- Close monitoring of risk implications of financial innovations and internationalization.

\section{Financial Restructuring in Pakistan}

In Pakistan, banking sector reforms were launched in the early 1990s. The objective of these reforms was to make the financial industry more competitive and transparent by privatizing formerly nationalized commercial banks, liberalizing interest rates and credit ceilings, strengthening the supervisory capacity of the central bank and standardized accounting and auditing systems (Iimi, 2004).

Prior to the 1990s, the financial sector in Pakistan remained heavily controlled $^{3}$. Interest rates were set administratively and usually remained negative in real terms. Monetary policy was conducted primarily through the direct allocation of credit. The money market was under-developed, and bond and equity markets were virtually nonexistent. Commercial banks often had to lend priority sectors with little concern for the borrowing firm's profitability. Despite the opening of the non-bank financial sector for private investment in the mid-1980s, state-owned financial institutions held almost $93.8 \%$ of the total assets of the entire financial sector at the end of the 1980s. Moreover, the status of financial institutions was precarious due to, inter alia, high intermediation costs resulting from overstaffing, a large number of loss-incurring branches, poor governance with low quality banking services, accumulation of non-performing loans and inadequate market capitalization. These inefficiencies and distortions caused severe macroeconomic difficulties in the late 1970s and 1980s and distorted economic growth. In order to remove these distortions and spur economic growth, the Government of Pakistan undertook a wide range of reforms in the early 1990s to strengthen its financial system and to provide an adequate macroeconomic environment.

The financial sector reforms included: (i) the liberalization of interest rates by switching from an administrated interest rate setting to a market based interest rate determination; (ii) the reduction of controls on credit by

\footnotetext{
${ }^{3}$ All commercial banks were nationalized in January, 1974, with the aim of making credit availability to high priority sectors of the economy which previously had limited access to investable funds (see Haque and Kardar, 1993 for a detailed account).
} 
gradually eliminating directed and subsidized credit schemes, (iii) the creation and encouragement of the development of a secondary market for government securities, (iv) strengthening the health and competition of the banking system by recapitalizing and restructuring the nationalized commercial banks (NCBs) increasing their autonomy and accountability, (v) improving the prudential regulations and supervision of all financial institutions, and (vi) allowing free entry of private banks in the financial market.

The financial sector reforms which were launched in the early $1990 \mathrm{~s}$ can be classified in three phases. These three phases of financial sector reforms can be termed as the first generation of reforms.

\section{III.A. First Phase of Financial Reforms (1988 -1996)}

The first phase reforms were aimed at creating an efficient, productive, and enabling environment for operational flexibility and functional autonomy. The first phase of financial reforms ${ }^{4}$ included: first, the government liberalized the market entry of private and foreign banks ${ }^{5}$ in order to gain efficiency and enhance competition within the financial sector. Secondly, two of the state-owned commercial banks, i.e. Muslim Commercial Bank (MCB) and Allied Bank Limited (ABL), were partially privatized between 1991 and 1993. Thirdly, major state-owned commercial banks and DFIs were downsized in terms of branches and employees. Fourthly, credit ceiling as an instrument of credit control was abolished, the Credit Deposit Ratio (CDR) was also abolished and open market operations is now an instrument of monetary policy and the State Bank of Pakistan (SBP) at regular intervals has conducted auctions of government securities. Fifthly, the loan recovery process was strengthened by establishing banking courts and standardizing loan classification and accounting rules. Finally, the State Bank of Pakistan was granted full autonomy. However, the segmentation of financial markets continued owing to continuing controls on interest rates on government debts and specialized credit programs.

\footnotetext{
4 The early phase of financial reforms as a part of financial restructuring policies started in the late 1980 s to early 1990 s.

${ }^{5}$ Ten new private banks started their operations in 1991 and 23 private domestic banks operating in the country including $\mathrm{HBL}, \mathrm{ABL}, \mathrm{MCB}$ and $\mathrm{UBL}$. The process of liberalization started in the early 1990s and except NBP, more than $50 \%$ shares of the public sector have been privatized. There are about 14 foreign banks that have been operating in the country.
} 


\section{III.B. Second Phase of Financial Reforms (1997-2001)}

In late 1996 the financial sector was on the verge of collapse (Table-3) with about one-third of banking assets stuck in the form of Non Performing Loans (NPLs). Liquidity problems had begun to emerge as disintermediation spread and banking losses increased. Most cases of loan defaults remained unresolved because of the ineffective judicial system. These problems were rooted in a failure of governance and lack of financial discipline. Political interference had vitiated the financial intermediation function of the banking system and the borrowers expected not to repay loans they took, especially from National Commercial Banks (NCBs) and Development Finance Institutions (DFIs). NCBs and DFIs were the main loss makers because over $90 \%$ of their loans were in default. Excess manpower, large branch network and undue interference by labor unions resulted in large operating losses. Poor disclosure standards and corruption were widespread. These serious problems created a demand for further reforms. As a result, the second phase of banking sector reforms ${ }^{6}$ was introduced in early 1997. These reforms addressed the fundamental causes of crisis and corruption and strengthened corporate governance and financial discipline. In this regard, the cost structure of banks was first restructured through capital maintenance and increased by public funds. Secondly, partially privatized commercial banks were privatized completely. Thirdly, bank branches were fully liberalized which allowed private banks to grow faster and increase their market share. Fourthly, loan collateral foreclosure was facilitated and strengthened to reduce default costs and to expand lending to lower tier markets, including consumer banking. Fifthly, national savings schemes were reformed so as to integrate with the financial market. Sixthly, the mandatory placement of foreign currency deposits was withdrawn. Lastly, the SBP was strengthened to play a more effective role as regulator and guardian of the banking sector and phase out the direct and concessional credit programs to promote market integration.

\footnotetext{
${ }^{6}$ The second phase of banking sector reforms started from 1997 to 2001 .
} 
Table-3: Selected Indicators of Vulnerability in Pakistan (Period ended 1996)

\section{Macro Indicator}

Inflation $>5 \%$

10.7

Fiscal Deficit $>2 \%$ of GDP

6.5

Public Debt $>50 \%$ of GDP

Yes

Current Account Deficit > 5\% of GDP

Short-term Flows $>50 \%$ of the Current Account Deficit

Yes

Capital Inflows $>5 \%$ of GDP

Yes

Ratio of Short-term Debt to International Reserves $>1$

Yes

Financial Sector Indicators

Recent Financial Sector Liberalization

Yes

Recent Capital Account Liberalization

No

Credit to the Private Sector $>100 \%$ of GDP

$17.1 \%$

Credit to the Private Sector (real growth) > 20\%

No

Emphasis on Collateral when making loans Yes

Estimated Share of Bank Lending to the Real Estate Sector $>20 \% \quad$ No

Stock of Non-performing Loans $>10 \%$ of Total Loans Yes

Stock Market Capitalization as \%age of GDP $20.11 \%$

Source: Lindgren et al (1999), p. 11

\section{III.C. Third Phase of Financial Sector Reforms (2002-2004)}

In this phase there were several major changes and significant positive shifts in the regulatory atmosphere to strengthen the financial system and introduce structural improvements. Some of the more important developments have been seen in the following areas:

Consolidation, Privatization and Regulation: During the 1990s, mushroom growth in commercial banks and non-bank financial institutions has been witnessed, a few of which have low capitalization, inadequate/inappropriate staffing, poor risk management practices and a marginal portfolio quality. The central bank sought out to consolidate the 
banking sector by raising the minimum capital requirement. The minimum capital requirement was 1 billion for 2003, 1.5 billion for 2004 and was set at 2 billion for 2005. There have been 17 mergers and acquisitions and there are several in the pipeline. Weak entities have been eliminated. The average capital base of a commercial bank has risen from 1.8 billion in 2000 to 3.7 billion in 2003 . Now all banks are required to maintain at least $8 \%$ of the risk weighted assets as capital requirement.

The regulatory oversight for a sizeable chunk of the financial system (such as leasing companies, modarabas, investment banks, mutual funds and insurance companies) has been moved to the Securities and Exchange Commission (SECP), but SECP failed to build capacity in order to handle this inflow. The SECP lacks on-site inspection capability.

Universal and Consumer Banking: Banks are allowed to form separate subsidiaries to function as mutual funds, asset management companies, venture capital, foreign exchange companies, etc. Furthermore, banks are encouraged to expand their lending operations to middle and lower income groups. A large range of consumer asset products such as credit cards, auto loans, clean installment loans, housing finance, etc., are being marketed aggressively. The NPLs in this sector are significantly lower than that of the corporate sector. Similarly, Small and Medium Enterprise (SME) financing has also become part of the lending toolkit. However, several banks shy away from this sector because of high-risk perception.

Automation and Prudential Regulations: ATM coverage is relatively low and on-line banking is offered by most of the banks. The Central Bank itself is making significant progress in this area. Credit information data and credit rating agencies data are now available on line.

Similarly, the Central Bank has been steadily moving away from its tradition of intrusive regulation and directed lending. Unlike the late 1980s, a much more permissive regulatory atmosphere prevails today. The Central Bank also modernized and revised prudential regulations for corporate and commercial banking, SME financing, microfinance institutions and consumer financing.

Banking Audit, Supervision and Corporate Governance: The SBP's compliance with the Basle Core Principles is generally high. The SBP now conducts comprehensive on-site inspections using a standardized 
CAMELSS $^{7}$ for rating the overall condition of a bank. The SBP is also developing an early warning system called $\mathrm{IRAF}^{8}$. For corporate governance, both the SBP and SECP issued codes of corporate governance. Corporate disclosure standards have improved. However, there is a need to reform the taxation structure and the tax collecting institutions.

Out-of-Court Settlement of NPLs: Two thirds of the stock of NPL involve a single lender. Recovery of NPLs involves internal and external hurdles. The pressure from influential borrowers is often exerted through the government. To reduce the level of NPLs, the government and the SBP established the committee for the revival of sick industrial units (CRSIU) and corporate and industrial restructuring corporation (CIRC). The committee claims that it has revived 172 industrial units involving outstanding NPLs of Rs. 46 billion. However, the World Bank concluded, regarding the assessment of CIRSU, that "in the absence of operational analysis, there would generally appear little increment in the value of the project. Future viability and renewed distress of these projects are of concern. No track is kept of financial or operational details of the projects after revival." In 2002 because of growing NPLs and the failure of CIRC, the National Accountability Bureau (NAB) and CIRSU, the SBP issued guidelines whereby banks are actively encouraged to settle NPLs with borrowers at the Fore Sale Value (FSV) of the underlying collateral. Under this scheme, borrowers were required to deposit $10 \%$ down payment at the time of signing the settlement agreement and repay the remaining amount in 12 quarterly installments. This scheme encourages a lot of defaulters to come forward and settle their long-standing liabilities. Similarly, under the debt recovery program, EDR (Excess Debt Recovery) had a write-off efficiency ratio of $5: 1$ (i.e. for each of the provisions written off it would generate a cash recovery of Rs. 5). Under these guidelines Rs. 52 billion of NPL have been settled at the cost of around Rs. 35 billions.

\section{Results of the Financial Restructuring}

The objectives of financial restructuring policies were to forestall a collapse of the generalized banking system and to establish a viable banking system in the country. It was expected that financial and operational restructuring policies strengthened the microeconomic foundations of the banking system. However, commercial banks have been slow to mobilize

\footnotetext{
${ }^{7}$ CAMELSS indicate Capital, Assets, Management, Earnings, Liquidity, and Sensitivity to Market Risk, Systems.

${ }^{8}$ IRAF indicate Institutional Risk Assessment Framework.
} 
deposits, which play a significant role in financial intermediation. As Akhtar (2007) pointed out, the successful transformation and restructuring of the financial industry depends on some critical factors such as: (i) promoting a higher degree of depth and efficiency in the financial intermediation process by effective resource mobilization and channeling these resources to promote economic growth, (ii) improving the financial performance and strengthening the soundness of financial institutions, and (iii) extending the outreach of financial services to the poor segment of society.

We therefore, briefly discuss the impact of the financial sector reforms under the following headings:

\section{IV.A. Interest Rate Policies}

Interest rates directly affect business conditions and economic activities and thus represent a powerful policy instrument. In Pakistan, before financial reforms, interest rates were set administratively and were often negative in real terms. For example, deposits were paid negative real return, thus discouraging savings in the country. Ceilings on interest rates were imposed with the desire to provide low-cost financing to encourage investment, particularly in the priority sectors. However, restrictions on interest rates led to financial disintermediation, as savers and investors sought alternative outlets outside the formal financial system. Consequently, financial deepening was hindered, and financial resources were not directed into productive activities.

After liberalization, the price of financial services was intended to be determined by the banks on a competitive basis, with little intervention from the SBP. To achieve the twin objectives of reducing the government's cost of borrowing on domestic debt and encouraging private sector credit expansion, the SBP had been pursuing a relatively easy monetary policy from July 1995 to July 2000. The weighted average lending rate gradually came down from $15.6 \%$ in 1998 to $8.81 \%{ }^{9}$ in June 2005 , but the real interest rate increased from $3.6 \%$ in 1996 to $10.9 \%$ in 2000 and then following a declining trend, reached $-0.49 \%$ in June 2005 (see Table-4). This reduction in the lending rate indicates little improvement in the profitability of the banks but is purely ad hoc and not in the line with liberalization. Similarly, the weighted average deposit rate declined from $6.8 \%$ in 1998 to $1.37 \%$ in June 2005; the real deposit rate remained negative except for the period 1999-2002. This reduction in the deposit rate will reduce savings even further.

\footnotetext{
${ }^{9}$ Although in 2004 the rate fell to $7.28 \%$.
} 
Table-4: Interest Rate Behavior in Pakistan

\begin{tabular}{lccccccc}
\hline \multirow{2}{*}{ Year } & \multirow{2}{*}{$\begin{array}{c}\text { Inflation } \\
\text { Rate }\end{array}$} & $\begin{array}{c}\text { Weighted average } \\
\text { Lending Rate }\end{array}$ & \multicolumn{2}{c}{$\begin{array}{c}\text { Weighted average } \\
\text { Deposit Rate }\end{array}$} & \multicolumn{2}{c}{$\begin{array}{c}\text { Interest Rate } \\
\text { Spread }\end{array}$} \\
\cline { 3 - 8 } & & Nominal & Real & Nominal & Real & Nominal & Real \\
\hline $1990-95$ & 10.57 & 12.55 & 1.98 & 6.53 & -4.05 & 6.02 & 5.95 \\
1996 & 10.8 & 14.4 & 3.6 & 6.4 & -4.4 & 8.00 & 8.00 \\
1997 & 11.8 & 14.6 & 2.8 & 6.8 & -5.0 & 7.8 & 7.8 \\
1998 & 7.8 & 15.6 & 7.8 & 6.8 & -1.0 & 8.8 & 8.8 \\
1999 & 5.7 & 14.8 & 9.1 & 6.5 & 0.8 & 8.3 & 8.3 \\
2000 & 3.6 & 13.52 & 10.9 & 5.47 & 1.9 & 8.05 & 9.00 \\
2001 & 4.4 & 13.61 & 9.21 & 5.27 & 0.87 & 8.34 & 8.34 \\
2002 & 3.5 & 13.19 & 9.69 & 3.61 & 0.11 & 9.58 & 9.58 \\
2003 & 3.1 & 9.40 & 6.3 & 1.61 & -1.49 & 7.79 & 7.79 \\
2004 & 4.6 & 7.28 & 2.68 & 0.95 & -3.65 & 6.33 & 6.33 \\
2005 & 9.3 & 8.81 & -0.49 & 1.37 & -7.93 & 7.44 & 7.44 \\
\hline
\end{tabular}

Source: SBP Annual Reports (various issues).

The interest rate spread ${ }^{10}$ is an important indicator for the financial sector's competitiveness, profitability and efficiency. Spread typically declines when competition among banks increases to access the financial market to increase their customer's base. But in Pakistan, the high lending rate and low deposit rate have generated a large spread ${ }^{11}$ nearing $7.44 \%$ in June 2005 as against $6.33 \%$ in 2004 . The high lending rate will increase the cost of borrowing and hence discourage investment. The low deposit rates discourage savings, resulting in a high debt/GDP ratio, deterioration of the banks balance sheets, lowering economic growth, and increasing poverty. Furthermore, the large spread also reflects a perceived sovereign risk (Khan, 2003).

However, the efforts of the SBP to enhance competition helped to narrow the spread to $6.33 \%$ in 2004 . But this trend was reversed and the spread rose again to $7.44 \%$ by the end of June 2005 and the commercial

\footnotetext{
${ }^{10}$ Interest Rate Spread $=($ Average Lending Rate - Average Deposit Rate $)$.

${ }^{11}$ High interest rate spread is generated by factors such as high administrative costs, overstaffing and unavoidable burden of non-performing loans (for further detail, See SBP's financial sector assessment 2003-2004).
} 
banks re-priced their loans in line with the upward adjustment in the SBP repo rate in the wake of high inflation without any rise in deposit rates. Hence, measures should be taken to bring down the interest rate spread close to zero in order to enhance both savings and investment in the country.

\section{IV.B. Performance and Efficiency of Financial Institutions}

The performance and efficiency of a financial institution involves two aspects, namely, solvency and sustainable profitability. Solvency improving measures affect the bank's balance sheet while profitability measures affect the bank's income. The improvement in the banking performance emanates from financial restructuring operations. NPLs can be used as an indicator to measure the performance of financial institutions. In Pakistan, the NCBs and the DFIs have been facing the problem of NPLs, which increased from Rs. 25 billion in 1989 to Rs. 128 billion in June 1998, or 4\% of GDP. Moreover, the NPLs increased from Rs. 230.7 billion in December 1999 to Rs. 240.1 billion in December 2000. However, some significant efforts were made by the government to recover default loans. As a result, NPLs, in gross as well as net terms have followed a declining trend since 2001 showing an improvement in loan appraisal standards and market discipline. Furthermore, as the banking sector registered a growth in advances, the ratio of NPLs to advances showed a sharp declining trend (Table-5).

Table-5: Non-performing Loans of the Banking System

\begin{tabular}{ccccc}
\hline Year & $\begin{array}{c}\text { NPL's (in } \\
\text { Billions) }\end{array}$ & $\begin{array}{c}\text { Gross NPLs to } \\
\text { Advances (in \%) }\end{array}$ & $\begin{array}{c}\text { Provisions to } \\
\text { NPLs (in \%) }\end{array}$ & $\begin{array}{c}\text { Net NPL to Net } \\
\text { Advances (in \%) }\end{array}$ \\
\hline 1997 & 173.0 & 23.5 & 46.6 & - \\
1998 & 183.0 & 23.1 & 58.6 & 11.1 \\
1999 & 230.7 & 25.9 & 48.6 & 15.3 \\
2000 & 240.1 & 23.5 & 55.0 & 12.2 \\
2001 & 244.1 & 23.4 & 54.7 & 12.1 \\
2002 & 231.5 & 21.8 & 60.6 & 9.9 \\
2003 & 222.7 & 17.0 & 63.9 & 6.9 \\
2004 & 211.2 & 11.6 & 70.4 & 3.8 \\
2005 & 177.3 & 8.3 & 76.7 & 2.1 \\
\hline
\end{tabular}

Source: SBP Annual report (various issues) 
The financial institutions succeeded in bringing down NPLs from $25.9 \%$ to $8.3 \%$ of the total advances of the banks and DFIs at the end of 2005. The net NPLs (net loan ratio), which is a more appropriate measure, was still about $2.1 \%$. These indicators reveal a very impressive performance by the banking sector because in late 1996, the banking system was on the verge of a crisis with about one-third of its assets stuck in the form of default and NPLs.

\section{IV.C. Money and Credit Policies}

In the late 1980s and early 1990s, Pakistan conducted its monetary policy through direct control on credit and interest rates. The banking system was not generally competitive and major banks were owned by the state. In addition, banks and other financial institutions were required to hold part of their portfolios in government debt at below market rates. The government directed bank loans to state owned-enterprises. The range of financial instruments available to banks and the public was intended to be narrow with maturity structures and yields unrelated to risk and liquidity.

In recent years, Pakistan has started to reform its monetary policy by using indirect or market-based instruments to achieve macroeconomic stability. In 1995, the SBP shifted the emphasis from direct to indirect instruments i.e. open market operations including a rediscount window, liquidity auctions, repurchase agreements and overdraft facility. The monetary authorities have sought to reduce direct government intervention and strengthen the role of market forces in allocating financial resources in order to improve the capacity of institutions to mobilize domestic savings, improve the effectiveness of monetary policy, enhance competition among banks and strengthen the banks' financial soundness.

To measure the improvement in the financial intermediation capacity of the banking system following the financial restructuring process, the standard indicators used in this paper include the ratios of currency to broad money (M2), ratio of currency to GDP, M2/GDP, M3/GDP, M1/M2, the ratio of private sector credit to GDP and market capitalization ${ }^{12}$. Table- 5 presents the entire situation after the introduction of financial sector reforms.

\footnotetext{
${ }^{12} \mathrm{M} 1$ is the currency in circulation plus demand deposits. M2 is M1 plus time deposit, foreign currency deposits. M3 is M2 plus other type of deposits, as well as short-term money market instruments such as certificates of deposits. In the case of Pakistan M3 includes M2 plus NSS, NBFIs.
} 
The ratio of currency to broad money (M2) would tend to fall in the financial environment where market forces dominate, where there are alternative saving investment instruments (stocks, bonds, mutual funds etc.) that raise the real rate of return, where there is confidence in the banking system and where access to the banking system has expanded. The ratio fell from $37.56 \%$ in 1990 to $23 \%$ in 2005 . This implies the dominance of market forces and retains the confidence of the customer in the banking system. Furthermore, the low ratio of currency to money mainly reflects advancement in the payment system, which heavily relies on credit cards, the development of the banking system and that money can be transferred between checking and savings accounts easily without any significant cost.

Table:- Indicators of Financial Deepening (in \%)

\begin{tabular}{|c|c|c|c|c|c|c|c|c|c|c|}
\hline Indic & $1961-70$ & $1971-80$ & $1981-90$ & 1990 & 2000 & 2001 & 2002 & 2003 & 2004 & 2005 \\
\hline urrency/ $\mathbf{M}_{2}$ & 45.13 & 32.29 & 32.28 & 37.56 & 27.80 & 26.02 & 25.30 & 25.04 & 23.99 & 23.00 \\
\hline Currency/GDP & 16.06 & 13.53 & 13.29 & 14.73 & 10.82 & 10.31 & 11.08 & 11.77 & 11.84 & 11.18 \\
\hline $\begin{array}{l}\text { Broad M } \\
\text { (M2)/GD }\end{array}$ & 34.0 & 33.90 & 41.24 & 39.24 & 38.93 & 39.64 & 43.80 & 46.99 & 49.36 & 48.61 \\
\hline M3/GDP & - & - & & .63 & 57.98 & 55.90 & 0.8 & 64.36 & & \\
\hline $\mathrm{M} 1 / \mathrm{M} 2$ & - & - & 67.10 & 76.01 & 59.32 & 58.48 & 58.01 & 61.23 & 61.78 & 72.48 \\
\hline $\begin{array}{l}\text { Privat } \\
\text { Credi }\end{array}$ & 19.60 & 19.24 & 21.45 & 19.92 & 22.33 & 22.02 & 21.92 & 24.87 & 29.30 & 28.44 \\
\hline $\begin{array}{l}\text { Stock market } \\
\text { capitalization/ } \\
\text { GDP }\end{array}$ & 8.42 & 4.08 & 3.75 & 4.68 & 10.24 & 8.15 & 9.26 & 15.48 & 24.05 & 30.95 \\
\hline
\end{tabular}

Sources: Calculated by authors using IFS and SBP data

During the financial restructuring process, the ratio of M2 to GDP tends to rise as access to banking and saving instruments spreads. But as markets mature, the ratio M2/GDP tends to decline as other financial instruments outside the M2 aggregate become available. The ratio M2/GDP which was $39.24 \%$ in 1999 , touched $48.61 \%$ at the end of 2005 . This is mainly due to the improvement of the domestic financial system.

The ratio of currency to GDP has decrease from $14.73 \%$ in 1990 to $11.18 \%$ in 2005 implying that the banking system is relatively developed. There are significant foreign currency deposits in the banking system and substantial real rates of interest on saving accounts in domestic currency. 
The ratio of M1/M2 provides a proxy for the extent to which the financial system of a country has succeeded in mobilizing savings. In 1990, the ratio was 76.01 , which came down to $58.01 \%$ in 2003 . This is mainly due to the development of the banking sector, a significant increase in foreign currency deposits and substantial real interest rate on savings. It started increasing from $58.01 \%$ from 2003 and touched $72.48 \%$ at the end of 2005 . This implies a reduction of savings due to the negative real rate returns on deposits.

The share of private sector credit to GDP is one of the important indicators of allocative efficiency when compared with that of the government sector. Credit to the private sector would be expected to expand when banks are successfully restructured. In addition, this ratio also reflects whether the private sector receives sufficient resources to carry out its economic activities. It has fuelled economic activity, revived and enhanced industrial capacity and supported steady growth in the services sector, the contribution of which to GDP is nearly $52.3 \%$. The ratio of private-sector credit to GDP increased from $19.92 \%$ in 1990 to $28.44 \%$ in 2005. In addition, fiscal adjustment efforts, privatization of some public enterprises and the liberalization of interest rates had all clearly enhanced the private sector's access to the banking system.

Stock market capitalization, which was $4.68 \%$ of GDP in 1990, is $30.95 \%$ of the GDP in 2005. This indicates the promotion of trading activities. However, the secondary market is not yet operating efficiently and remains very thin and bank financing remains the main source of funds for productive investment. Furthermore, foreign access to the stock market is limited because of a number of factors including macroeconomic weaknesses, inadequate transparency and accounting standards and a cumbersome and opaque regulation environment. In addition, there are some restrictions on the capital movements for non-residents and also ceilings on non-residents' shares in companies' equity. Moreover, bond markets barely constitute $5-7 \%$ of GDP and there is low pension and insurance coverage.

\section{IV.D. Profitability and Financial Soundness}

After years of poor profitability, the returns on assets and equity are beginning to increase. Net interest income decreased from $69 \%$ in 2001 to $58.2 \%$ in 2003 . This reduction of net interest income is mainly due to a contraction in interest margin. As a result, the share of net interest income in gross income declined to $58.2 \%$ (Table-6). 
Table-6: Banking Sector Earnings and Profitability.

\begin{tabular}{lccccc}
\hline Earning and Profitability & $\mathbf{1 9 9 9}$ & $\mathbf{2 0 0 0}$ & $\mathbf{2 0 0 1}$ & $\mathbf{2 0 0 2}$ & $\mathbf{2 0 0 3}$ \\
\hline Return on assets after tax & -0.2 & -0.2 & -0.5 & 0.1 & 1.0 \\
Return on equity after tax & -6.2 & -0.3 & -0.3 & 13.8 & 22.1 \\
Net interest income to gross income & 54.3 & 61.2 & 68.9 & 67.4 & 58.2 \\
Non-interest expenses to gross income & 76.9 & 71.6 & 62.7 & 57.3 & 50.4 \\
Personnel expenses to non-interest & 57.0 & 54.3 & 52.6 & 51.4 & 50.1 \\
expenses & & & & & \\
Non-interest income to total income & 17.6 & 16.5 & 14.5 & 18.1 & 30.9 \\
\hline
\end{tabular}

Source: State Bank of Pakistan

Akhtar (2007) has pointed out that the profits of commercial banks crossed over $\$ 1$ billion for the first three quarters of 2006. She further noted that from 2000-2006, the returns on assets of banks rose from $-0.2 \%$ to $2.1 \%$ and return on equity from $-3.5 \%$ to $26.1 \%$. This increase in profit may be attributed to many factors such as: (i) a rise in earning assets of commercial banks to $85 \%$ in September 2006 which is significantly above the pre-reform period and a rise in advances to total assets from $49.1 \%$ in 2000 to $55.1 \%$ in September 2006, (ii) a decline in total and operating expenses, (iii) a rise in the SME, consumer finance and agriculture sector lending which constitutes over one third of total outstanding advances, (iv) a high share of non-interest bearing deposits and declining share of fixed deposits, and (v) a growth of service charges by the use of electronic banking. Furthermore, it can be argued that the privatization of the financial industry has had a distinct impact on the profitability of the banking sector, though its impact on efficiency is relatively weak ${ }^{13}$. However, it is expected that over a period of time there will be more progress in these areas.

\section{IV.E. Privatization Policy}

The structure of the financial sector in Pakistan has substantially changed following privatization of the state-owned commercial banks. In 1990, the financial system was fully dominated by five state-owned commercial banks. During the first round of financial sector reforms, two state-owned commercial banks - Muslim Commercial Bank (MCB) and Allied Bank Limited (ABL) - were privatized between 1991 and 1993. The reform process was subsequently delayed for several years and again resumed in the

${ }^{13}$ State Bank of Pakistan (2005). 
early 2000s. With the privatization of the third largest commercial bank, United Bank Limited (UBL), in 2002, the domination of the state-owned commercial banks was ended. As of September 2003, the asset share of domestic private banks and public sector commercial banks was $47 \%$ and $41 \%$ respectively. Furthermore, when the privatization of Habib Bank Limited (HBL) was completed in 2004, the share of the assets of the banking system held by public sector commercial banks decreased to less than 25\%. Today, the National Bank of Pakistan (NBP) is the only stateowned commercial bank with a market share of approximately $20 \%$.

The privatization of nationalized commercial banks and DFIs poses a serious challenge to the government. The government facilitated bank restructuring process by recapitalization of banks through (i) equity injection of Rs. 46 billion in some of the public sector banks and write offs equivalent to Rs. 51 billion, (ii) lay-off of close to 35,000 employees in two phases ${ }^{14}$ from public banks, and (iii) the closing of over 2000 loss incurring bank branches.

\section{IV.F. Corporate Governance}

The efforts of SBP helped in bringing a positive change in the corporate governance standards of banks. Banks and other financial institutions are now managed by a better cadre of professionals and stakeholders now play an active role in the affairs of banks. Regular board meetings, financial reporting standards, disclosure and transparency helped to improve corporate governance. Improvement in corporate governance helped to ensure a high degree of financial stability.

From December 2002 to December 2005, the balance sheet of the banking system has recorded a growth of $64.5 \%$, which is quite significant. Since 2002, the deposits of the banking system registered a growth of $69 \%$. Returns on assets after tax increased from $0.1 \%$ in 2002 to $1.9 \%$ in 2005 and further increased to $2.1 \%$ by the end of September 2006. The loan portfolio of the banking system doubled in the last three years. Credit growth is now fairly diversified. All these achievements have resulted owing to good governance policies.

On the basis of the above analysis, we reached the following conclusions:

- Financial markets have now become more competitive and relatively efficient but still remain shallow. There are many financial

\footnotetext{
${ }^{14}$ In 1997 almost 24000 employees were laid off and in the second phase around 11,700 employees were relieved (Akhtar, 2007).
} 
instruments available for transactions but the evolution of new instruments has to remain on track.

- Although financial infrastructure has been strengthened, the legal system is still complicated, time consuming and costly for ordinary customers. Furthermore, the regulatory environment has been improved and the monitoring system is much better today but enforcement and corrective capabilities need to be further strengthened.

- The further development of long-term bond markets, further improvements of corporate governance, reinforcement of regulatory and supervisory arrangements, the expansion of investors' base, improvement of equity market infrastructure, revaluation of market volatility-controlling mechanisms and sequencing the reforms also need to be enhanced.

\section{The Second Generation of Reforms}

The first generation of reforms launched in the early 1990s gained roots and the financial industry in Pakistan is now ready to shift its focus to a second generation of reforms. The second generation reforms will not only help in achieving macroeconomic stability but also create an enabling environment for sustainable economic growth. Institutional strengthening, macroeconomic stability, protection of property rights, and legal and financial infrastructure development should be the main pillars of the second generation of reforms. The main ingredients of second generation of reforms include:

\section{(i) Macroeconomic Stability}

It can be thought that the banking system could easily be weakened by high and volatile real interest rates, owing to inappropriate fiscal policies that entail excessive borrowing from the commercial banks, inefficiencies in the payment system that encourage fraud, and loss-incurring banks. In order to maintain stability within the liberalized financial system, it is necessary to ensure that the fiscal position should be sound, banks should be well capitalized, and the payment systems should be modernized. To achieve these objectives the authorities should ensure stable and enabling macroeconomic conditions because it is inadequate to promote financial liberalization when the structural and macroeconomic problems remain unresolved.

\section{(ii) Improvement in Governance}

An improvement in governance would ensure greater transparency and accountability, a more secure and predictable environment for domestic 
and foreign investment, and promote greater ownership of the reform efforts. In Pakistan there is still a need to clarify rules related to governance. Hence, attention should be paid to clarification and rules should be conformed so that they are consistent with international standard.

(iii) Strengthen Institutional Capacity and Protection of Property Rights.

For economic stabilization and sustainable economic growth, institutional strengthening and the risk taking ability of economic agents is necessary. Macroeconomic stabilization requires strong institutional coordination between the monetary and fiscal authorities. Strong institutions and protection and simplification of property rights should be given an important place in the second generation reform agenda. Furthermore, upgradation and the encouragement of institutions such as SMEs, microfinance, consumer finance, housing finance and rural banking will accelerate the momentum of the financial industry because of the access of the vast majority of the population to financial services. Hence, there is an urgent need to further develop and strengthen these institutions.

\section{(iv) Streamline Venture Capital Funds and Private Equity Funds}

Venture capital and private equity funds, private pension and provident funds and insurance companies are the most effective means for financing innovative firms in the economy. The authorities should streamline these funds and encourage their growth.

\section{(v) Strengthen the Legal and Financial Infrastructure}

The accountability and enforcement of financial contracts requires that we have a legal system that dispenses justice quickly and inexpensively. But our legal procedure is too lengthy. There is a need to review banking laws and procedures to make them simple and less abrupt. Hence, this area needs special attention.

\section{Conclusions}

Financial restructuring is a continuous process not an event. Prior to 1990, the financial sector in Pakistan was characterized by weakness in banking and corporate governance, weak accounting standards, lack of market discipline, weak prudential regulations and poor legal infrastructure. These problems increased the exposure of financial institutions to a variety of external threats, including a decline in the values of assets, market contagion, speculative attacks, exchange rate devaluation, and a reversal of capital flows. Furthermore, capital flight and disrupted credit allocation further caused a 
deterioration in the efficiency of the banking sector. In the background of the arising situations of the financial sector in Pakistan, a number of restructuring measures were undertaken since 1990 with a view to restore financial discipline and improve the operational efficiency of the financial sector. The financial sector restructuring program was instituted in 1990 and was concluded in 2004. In response to financial restructuring measures, financial discipline and operational efficiency shows significant improvement today as compared to pre-1990. Pakistan has made considerable progress during the past one and half decades in reforming its financial sector. Financial restructuring and privatization have changed the landscape of the financial industry in Pakistan. However, the secondary market is relatively thin and as such the supply of corporate securities remains small but the change is more fundamental in banking relative to equity markets. The development of the capital market is related to a range of economic, financial, institutional and legal factors that need to be addressed properly.

Furthermore, the legal infrastructure must be developed for financial supervision, bankruptcy and foreclosure. Bank secrecy laws should be improved to enhance transparency and a deposit insurance scheme is needed to maintain confidence in the financial system. An early warning system and prompt corrective actions are needed. The study further concludes that without further improvement of corporate governance and expansion of the investor's base, capital markets cannot be developed. Moreover, until the equity markets are strengthened, the capital market cannot function well to complement the banking sector. More openness, together with more transparency and the disclosure of information, should contribute significantly to the financial restructuring of the economy and integration into the global economy. Although Pakistan restructured its financial sector successfully within a very short period, the sustainability and performance of financial sector reforms are required (Akhtar, 2007):

- Macroeconomic stability,

- A greater degree of consolidation should be necessary for strong and robust banking,

- Prudent regulatory and supervisory framework,

- Maturity and reorientation of financial industry,

- A well diversified and competitive financial system is still needed,

- Strong corporate governance, effective risk management system and mitigation, and 
- The financial system should be socially inclusive and should facilitate access to financial services.

\section{References}

Akhtar, S., 2007, "Pakistan Banking Sector- The Need for Second Tier of Reforms”, Bank of International Settlement Review, Vo1. 5, pp. 1-6.

Akhtar, S., 2007, "Pakistan Banking Sector Reforms: Performance and Challenges", Speech delivered by Dr. Shamshad Akhtar Governor State Bank of Pakistan, Geneva, 1 February 2007.

Alexander, William E, Tomas Balino and Charles Enoch, 1995, "The Adoption of Indirect Instruments of Monetary Policy”, Occasional paper 126, (Washington: International Monetary Fund).

Alawode, A.A. and S.I. Ikhide, 1977, "Why Should Financial Liberalization Induce Financial Crisis?”, Saving and Development, Vol. XXI, No. 3.

Bakros, Lajos, Alexander Heming and Carivotava, 2001, "Financial Transition in Europe and Central Asia: Challenges of the New Decade" (ed), The World Bank (Washington D.C.).

Borish, Michae1 S, Millard F. Long and Miche1 Noe1, 1995, "Restructuring Banks and Enterprise: Recent Lesson from Transition Countries”, World Bank Discussion Paper No. 279, (Washington D.C.).

Barth Richard, Alan R. Roe, and Chorng-Huey Wong (ed.), IMF Institute (Washinton: International Monetary Fund).

Chowdhury, Anis, 2000, "Politics, Society and Financial Sector Reform in Bangladesh”, WIDER Working Paper No. 191, The United Nations University.

Caprio Jr. G, and D. Klingebie1, 1996, "Bank Insolvency: Bad Luck, Bad Policy or Bad Banking?” Annual Conference on Development Economics, The World Bank.

Dalla, Ismail, Deena Khatkhate, 1995, "Regulated Deregulation of the Financial System in Korea”, World Bank Discussion Paper No. 292 (Washington D.C.). 
Dziobek, C. and C. Pazarbasiog1u, 1998, "Lesson from Systemic Bank Restructuring: Experience of 24 Countries”, IMF Survey, January 12, 1998 .

Eastwe11, J., 1996, "International Capital Liberalization: The record", CEPA Working Paper Series No. 1, University of Cambridge.

Fazil, Muhammad Sharif Bin, 1995, "Need and Scope for Further Reforms in the Financial Sector in Pakistan”, Journal of Islamic Banking and Finance, Vol. 12, No.5.

Hoelscher, David S., 1998, "Banking System Restructuring in Kazakhstan", IMF Working Paper No. 96 (Washington: International Monetary Fund).

International Monetary Fund, 1995, "Benefits of Capital Hows Tied to Strong Risk Management”, IMF Survey, June, Washington.

International Monetary Fund, 1996, "A11 Countries Share in Effects of Globalization”, IMF Survey, June, Washington.

Iqbal, Zubair (2001). "Macroeconomic Issues and Policies in the Middle East and North Africa”, International Monetary Fund (ed).

Iimi, Atsushi, 2004, "Banking Sector Reforms in Pakistan: Economies of Scale and Scope, and Cost Complementarities”, Journal of Asian Economics, Vol. 15, pp. 507-528.

Jhili, Abdelali, Klaus Ender and Volker Treiche1, 1997, "Financial Sector Reforms in Algeria, Morocca, and Tunisia: A Preliminary Assessment”, IMF Working Paper No. 81 (Washington: International Monetary Fund).

Haque, Nadeem U1 and Shahid Kardar, 1993, "Constraints to the Development of Financial Markets in Pakistan”, IMF, Mimeo.

Khan, Ashfaq Hasan, 1995, "Need and Scope for Further Reforms in the Financial Sector in Pakistan", Journal of the Institute of Bankers in Pakistan, June 1995.

Khatkhate, D., 1998, “Timing and Sequencing of Financial Sector Reforms: Evidence and Rationales”, Economic and Political Weekly, July 11, 1998. 
Lindgren, Car1-Johan, Tomas J. T. Balino, C. Enoch, A-M. Gulde, M. Quintyn, and L. Teo, 1999, "Financial Sector Crisis and Restructuring Lesson from Asian”, IMF Occasional Paper No. 188, International Monetary Fund, Washington: D.C.

McKinnon, R.I., 1973, "Money and Capital in Economic Development", Washington, DC: Brookings Institution.

Mavrotas, G. and R. Kelly, 2001, "Saving Mobilization and Financial Sector Development: The Nexus”, Saving and Development, Vol. XXV, No. 1.

Mishkin, F. S., 1996, "Understanding Financial Crisis: A Developing Country Perspective”, Annual Conference on Development Economics, The World Bank.

Sundararajan, V., 1996, "The Role of Prudential Supervision and Financial Restructuring of Banks during Transition to Indirect Instruments of Monetary Control". IMF Working Paper No. 128. (Washington: International Monetary Fund).

Sundararajan, V., 1994, "Interaction between Monetary Control and Financial Sector Reforms in Co-ordinating Stabilization and Structural Reforms.”

Shaw, E. (1973), Financial Deepening in Economic Development, New York: Oxford University Press.

Sheng, A., 1996, "Bank Restructuring: Lesson from the 1980s", The World Bank.

State Bank of Pakistan, 2005, "Financial Sector Assessment 2005", State Bank of Pakistan, Karachi.

Villanueva Belano and Abbas Mirakhor, 1990, "Strategies for Financial Reforms: Interest Rate Policies, Stabilization and Bank Supervision in Developing Countries". IMF Staff Paper, Vol. 37, No.3.

Vittas, D., 1992, "Introduction and Overview" in D. Vittas (eds.) Financial Regulations: Changing the Rule of the Game, Washington, D.C: EDI Development Studies, World Bank. 
Ziobek, Claudia and Ceyla Pazarbasioglu, 1997, "Lesson from Systemic Bank Restructuring: A Survey of 24 Countries”, IMF Working Paper No. 161, (Washington: International Monetary Fund).

Zaheer, Zahid, 2002, "Impact of Financial Restructuring on the Pakistani Economy”, Pakistan Business Review, Vol. 4, No.1. 